\title{
Construction of Social Space and Class Stratification in Charles Dickens' Great Expectations
}

\author{
Irfan Dupovac ${ }^{1}$ \\ ${ }^{1}$ International Burch University, Bosnia and Herzegovina \\ Email: irfandupovac97@gmail.com
}

DOI: $10.53103 /$ cjlls.v1i3.21

\begin{abstract}
The conventional English social class system was based on a rigid social structure that depended on family background and occupation. However, following the industrial revolution in the 19th century, people could move from one social class to another. In Great Expectations, Charles Dickens utilizes various sub-spaces of social space to emphasize the blend between the rigid class system of the Victorian era and the newfound social mobility. Through the journey of Pip, and other characters, including Miss Havisham, Miss Estelle, and Magwitch, among others, Charles Dickens manages to explore physical and psychological spaces across the social classes and how they interact to dictate the social space. By constructing social space, Great Expectations evaluates the stratification of the social classes ranging from the lowest class of outcast criminals to the rich upper class, and how various aspects, such as morality, wealth, and value system changes as one moves from one class to another.
\end{abstract}

Keywords: Great Expectations, Class Stratification, Social Space, Social Mobility, Physical Space, Psychological Space

\section{Introduction}

The conventional English social class system was based on a rigid social structure that depended on family background and occupation. However, in the new structure of class ranking, the emphasis was also put on the morality and character of a person. Resultantly, the novel structure following the onset of the industrial revolution offered an opportunity for mobility and attainment of new positions in the society through personal effort. Charles Dickens' Great Expectations presents themes of social mobility and class stratification through its main character, Pip, and other characters, including Magwitch, Miss Havisham, and Miss Estelle (Upham, 2012, p.1). Primarily, space is made up of three realms, an objectively physical space, a subjectively psychological space, and practically social space (Tang \&Lihui, 2015, p. 52). Social space combines physical and psychological space. Through the physical space, in the context of wealth and difference of living, the ideal space, which is hugely expressed through internal monologues and conversations between the young and the old Pip, and the practico-sensory realm of social space, Great 
Expectations successful showcases social stratification and the potential to move from one class to another (Tang \& Liu, 2015, p.55). In Great Expectations, social space has mainly been constructed through the acquisition of physical wealth, education, and status to facilitate social mobility from the lower to the upper classes of the Victorian England class system.

\section{Construction of Social Space}

Social space in Great Expectations incorporates the social environment, cultural context, the inner world, and the correlation between them, along with their mutual interaction. First, social space is portrayed through the aspect of the social environment in the depiction of physical space in the novel (Tang \& Liu, 2015, p.53). A gap in social class is portrayed through the differentiation between the social environment of the Blacksmith and the Manor House. Initially, Pip enjoys a quiet and happy life living with Mr. and Mrs. Joe. Pip's life at the forge, although simple, was satisfactory; Pip did not have any great ambition as he believed that working at the forge was his path to manhood and independence (Dickens, 1861, p. 93). However, following Pip's visit to the Manor House, an indicator of the higher class, where he met Miss Havisham and Miss Estella, Pip noticed his inferiority to the people in the upper class. The visit to the Manor House resulted in a sharp change in value. Through the contrast between Blacksmith and the Manor House, Charles Dickens manages to showcase the role of physical property in the construction of social space. Pip blamed his inability to purse Miss Estelle on his lack of wealth and inability to act like a gentleman in the upper class. Moreover, although Miss Estelle was born by a parent in a criminal class, which is the lowest social class in the Victorian English class system, she manages to fit into the upper class due to the possession of greater wealth and superior psychological strength. Moreover, Pip's comparison of his ordinary and vulgar life to that of a gentleman in the upper class makes him look down upon his social identity, and thus emphasizing the importance of physical wealth in the creation of social space.

The relevance of physical wealth in the construction of social space is evident through social mobility. Other than the sharp separation between the physical space of the forge and the Manor House, Pip's movement from the simple life at the forge to the new life in London was facilitated by him stumbling upon wealth (Tang \& Liu, 2015, p.53). Dickens cuts off the Manor House from the outside world, with Pip's interaction with the upper class leading to the tremendous change in value. To transition from the lower social class to the upper class, Pip had to come into a lot of money that he received from a secret benefactor, who is later revealed to be Magwitch. With the money, Pip manages to go to London, where he learns to become a gentleman. With the aid of his newly acquired wealth, Pip is successfully absorbed into the upper class, interacting with people from his new class, wearing better clothes, and speaking more formally (Tang \& Liu, 2015, p.53). In 
Pip's opinion, he has a better chance of wooing Miss Estelle because of his newly acquired wealth and social class. Therefore, aside from the physical space, Charles Dickens showcases the psychological space of thoughts and opinion, which is linked with societal and physical imagination.

Also, social space is observed in the presentation of the internal perception and subjective psychological space of the characters in Great Expectations. Through Pip's internal monologue, one can easily observe the vague class-consciousness (Tang Tang \& Liu, 2015, p.53). Pip's mental state, especially his feeling of inferiority following his interaction with Miss Havisham and Miss Estelle, emphasizes the class system of Victorian England. Although Pip is in love with Miss Estelle, he feels that he is not worthy because she comes from the upper social class (Tang \& Liu, 2015, p.54). Even after going to London, Pip does not fit right into the upper class. He had to improve his education, learn how to behave like a gentleman, and improve his communication skills. The behavioral improvement through education was made to satisfy the societal perspective of how a person in the upper class should behave. Also, Great Expectations displays the attitude of characters towards other characters from a different social class. Due to the common internal perception, the lower class looks up to people from the upper class, while those from the upper class look down on people from the lower class (Miah, 2014, p. 3). Through Pip's internal monologue, readers realize that Pip looks down upon Joe. After acquiring wealth and moving to London, Pip becomes ashamed of his origin and neglects his family in the process. After interacting with people from the upper class, Pip develops discomfort towards his brother-in-law, Joe, and sister (Tang \& Liu, 2015, p.53). He even felt uncomfortable when he attended his sister's funeral. Pip developed depression and a confused state of mind in his effort to satisfy the societal setting of how a person in the upper social class should behave.

Aside from the economic and academic sub-spaces and their unequal distribution in the society, social space in Great Expectations is also constructed through the interaction between intellects and the active exclusion of undesirable individuals. People from the lower class are deprived of the assets necessary to participate in the various social activities of intellectuals in London. Aside from the effect of stigmatization, with people from the lower classes feeling inferior, the development of a club of intellectual results in the effect of redoubling dispossession, especially in the cultural realm, with the intellects feeling culturally privileged compared to the rest of the society (Bourdieu, 2018, p. 109). In London, Pip manages to interact with Herbert Pocket and Wemmick, people who would be considered gentlemen in society. Pip accrues debt just to manage their undisciplined life in London. His loss of assets, however, deprived him of the necessary assets to facilitate his way of life in London.

In sum, Charles Dickens' Great Expectations combines physical and psychological space to develop the Victorian England class system that was dominated by strict class 
stratification. A sharp separation of the physical space, with the upper class represented by great wealth and the lower class with poverty, is evident through the comparison of Blacksmith, the Manor House, and Pip's life in London. Elsewhere, the psychological space is portrayed through the internal perception and attitude towards fellow characters. In Great Expectations, people of the lower class look up to individuals in the upper class, while those in the upper class despise persons in the lower class. Pip states that "throughout life, our worst weaknesses and meanness are usually committed for the sake of the people who we most despise" to stress the role of social class in dictating how people treat each other in society (Dickens, 1861, p. 192). Pip's confusion about the class system spearheads the development of the plot around self-discovery and self-definition. Rather than being born to a predetermined social class, Pip moves from one physical and mental space to the other through social mobility.

\section{Class Stratification}

Class stratification in Great Expectations combines the old model of class ranking in 19th century England and the new model that relied on morality and the character of an individual. Unlike the traditional class model that is very rigid and does not facilitate movement from one class to another, the new model encompasses social mobility (Upham, 2012, p. 2). Although Great Expectations looks into class stratification in the Victorian era, which ranges from the lowest class of criminals to the upper class of the very rich, it also encompasses the new social structure through Pip's movement from his working-class origin to becoming a gentleman.

The novel Great Expectations paints accurate portraiture of a working-class rural England family through the life of Mr. and Mrs. Joe and Pip. The Blacksmith family in Great Expectations is the representation of domestic reality as they actuate the life of poor common laborers of nineteenth-century England (Miah, 2014, p. 3). Unlike people who were brought up in an upper social class, as in the case of Miss Estelle, persons in the lower class relied upon their income and education level to move to a more reputable class. In most instances, families assumed the same social classification as they were born into, as most of them were dedicated to family-owned businesses and trades (Upham, 2012, p. 3). Pip was initially satisfied with being an apprentice at Joe's forge and assumed it to be the path to manhood and independence. Thus, the automatic determination of social class within families provided little room for shifting from one social class to another, as it was in the case of Pip. To successfully move into the upper class of society, people born into the common class had to rely on their income and education level. In Great Expectations, Pip is the only character that moves freely from one class to another.

Pip's ability to move from one class to another is only provided by a benefactor and not his family or a predestined career path. The opportunity to become educated as a 
gentleman granted him a chance for mobility to the higher societal class that most common class people cannot gain on their own (Upham, 2012, p. 16). Charles Dickens shows the changes in the definition of social classes in the 1800s through Pip's successful movement from one social class to another. In the new form of class stratification, morality was central in determining a higher societal class; morality was relied upon to achieve a higher class. Education had the role of instilling the desired morals in an individual; in Great Expectations, a person has the potential to educate himself or herself to achieve the desired status (Upham, 2012, p. 17). Thus, by giving him money and education, Pip acquired the necessary elements required to join the upper class in society- this contradicted the traditional social structure, where the place of birth played a significant role in determining an individual's class. The idea that Pip demolished his predestined role of being a blacksmith by simply acquiring wealth and education strays away from the traditional rigid structure in British society.

Although the working-class population was categorized into the lower class, criminals ranked lower, as is evident in Great Expectations. Despite the fact that Pip acquired his wealth from a criminal benefactor, Magwitch, he at first despises him. He feels bad that he is associated with wealth that was acquired through criminal means. Although Pip later realizes that physical possession and social class are not as important as affection, morality, and loyalty, he judged Magwitch based on the strict class system (Upham, 2012, p. 17). Therefore, based on the morality and character of individuals, criminals, such as Magwitch and Compeyson rank below the common laborers class. Similarly, Pip still possesses the ability to move from one social class to another, as it is evident in his criminal dealings, particularly helping Magwitch get out of the country. Pip takes up the life of a criminal without facing any punishment from society. By temporarily taking up the role of a criminal, Pip defies the traditional social structure.

The sharp difference between the lower and the upper classes in Victorian England is depicted in Great Expectations, through Miss Havisham and the Manor House. The upper class ranks higher than the lower class in terms of property wealth, power, and status (Tang \& Liu, 2015, p.53). The interaction between the family of Miss Havisham and the Blacksmith family was very limited. The physical space of the lower and the upper class was hugely divided. In addition, since people from the upper class were more educated, they were perceived by society to be of higher status (Tang \& Liu, 2015, p.53). The interaction between Pip and Miss Estelle portrays the psychological contrast between the two social classes. People from the upper class are arrogant when they interact with the common laborers; Miss Estelle was arrogant to Pip due to Pip's poor background and ignorant behavior. Due to the limited interaction across the social classes, it was difficult for Pip to woo Miss Estelle (Tang \& Liu, 2015, p. 53). The upper class is also reluctant in supporting people from the lower class to move into the upper class. For instance, in Great Expectations, Miss Havisham chooses to pay for Pip's apprenticeship in Mr. Joe's forge 
instead of helping him to pursue a noble career that would help him move to a higher social class. In another example, when Pip acquires wealth and moves to London to become a gentleman, his attitude towards Mr. Joe and his sister changed. Pip was uncomfortable around his brother-in-law and his sister. He began to complain about the ordinary and vulgar life at the forge, showing a significant change in attitude towards the lower class, despite the close relationship Pip is expected to have with his next of kin (Tang \& Liu, 2015 , p. 53). The upper class, which is characterized by wealthier and more educated persons, had limited interactions with people from the common class, as is evident in the interaction between Miss Havisham and young Pip.

Charles Dickens also analyzes social stratification by exploring the behavioral change across social classes. Mobility across the social classes also resulted in the overturning of individual value systems. Initially, young Pip is innocent, warm-hearted, and without any great ambition (Tang \& Liu, 2015, p. 53). He showcased kindness in how he treated Magwitch, who was below his social class. However, following his visit to the Manor House, his values changed tremendously. Pip developed a wicked personality characterized by snobbish and hypocritical traits (Tang \& Liu, 2015, p.53). Pip was no longer proud of his humble background. He blamed Joe for his inability to pursue Miss Estelle. Pip viewed the social identity of his family as a great shame. Furthermore, following his acquisition of wealth, Pip cuts his relationship with Joe and his sister and finds great discomfort around them. Thus, Charles Dickens' Great Expectations emphasizes the tremendous change in values that comes with the acquisition of a higher social class- people in the upper class, as evident from Miss Havisham, Miss Estelle, and Pip's attitude and behavior.

Although the social structure in Great Expectations is based on the class system of Victorian England, social mobility is evident as characters can move from one social class to another. Contrary to the traditional structure, where a person's social class was predetermined, the new model that came up following the industrial revolution facilitated social mobility (Puji \& Thoyibi, 2018, p. 2). Although the society has maintained the social class stratification, where the upper class possesses more wealth, greater respect, and power compared to the lower class, the rigidity that existed in the old model is no longer there (Puji \& Thoyibi, 2018, 2). Pip successfully moves from being a common laborer in the lower class to becoming a gentleman in the upper class. Movement down the social class is also possible, as evident in Pip's downfall following the confiscation of Magwitch's wealth. Moreover, Pip's social mobility is seen in his ability to also take up the lower criminal social class by helping Magwitch. Furthermore, even Miss Havisham's wealth is acquired through commerce, suggesting potential social mobility. Therefore, Charles Dickens combines the idea of the traditional Victorian England class system with the new model following the industrial revolution and thus facilitating Pip's movement across the social classes. 


\section{Conclusion}

In conclusion, Great Expectations showcases various methods of constructing social space and how they facilitate class stratification. The environment of Great Expectations is based on the nineteenth-century British society that was predominantly based on the class system of Victorian England. In constructing social space, Charles Dickens incorporates the physical space and the psychological space- the mutual interaction between social environment, scene, cultural background, the inner world dictated the social space in Great Expectations. The physical space is evident through the sharp physical separation between the Blacksmith and the Manor House. While the upper class is characterized by greater physical wealth, the lower class is deprived of physical wealth. The physical space of the two classes does not interact. Furthermore, the subjective psychological space of the characters plays a key role in the interaction between individuals from different social classes. While people from the upper class are more educated, the lower class is characterized by ignorant behaviors. Due to the psychological space, people from the lower class, such as young Pip, feel inferior to the more arrogant people in the upper class. Intellectual sub-space is also evident in Great Expectations. Social space facilitates class stratification. Society is divided into various social classes, ranging from the lowest class of criminals to the highest social class of the very rich. Ideally, the movement from one social class to another is difficult, with many people remaining in social classes they were born into. However, unlike other characters, Pip manages to move flexibly from one social class to another. However, based on the new social structure, a person can move up his social class by acquiring income and education, going against the traditional rigid social structure. For the most part of the novel, the upper class despises the lower class, as it is evident with Miss Havisham, Miss Estelle, and Pip. The upper class is associated with evil. Unlike in the lower class, where Pip showed kindness and satisfaction with whatever life offers, Pip becomes distant from his family because he is not proud of it. Through the combination of the traditional Victorian England class system and the new social structure, Charles Dickens manages to show the transition in social class and stratification that allows social mobility following the industrial revolution.

\section{References}

Bourdieu, P. (2018). Social space and the genesis of appropriated physical space. International Journal of Urban and Regional Research, 42 (1), 106-114.

Dickens, C. (1861). Great Expectations. Vol. 1. JB Peterson \& Bros.

Miah, M. M. (2014). Great Expectations and the Ballad of the Road: Simple Annals of the Poor. GSTF Journal on Education (JED) 1.1.

Puji, A., \& Thoyibi. M. (2018). Social mobility in Charles Dickens' Great Expectations novel (1861): A Marxist perspective. Diss. Universitas Muhammadiyah Surakarta.

Tang, T., \& Liu, L. (2015). Pip's cognitive development in Great Expectations from the 
viewpoint of space product. Studies in Literature and Language, 10(1), 51-57.

Upham, A. (2012). Class structure in Great Expectations: Dictate Your Own Fate. Retrieved from https://fisherpub.sjfc.edu/english_seniorseminar/4/ 